\title{
МЕНЕДЖМЕНТ
}

УДК 330.131 .7

DOI: https://doi.org/10.26642/jen-2021-4(98)-37-41

\author{
А.М. Бричко, к.е.н., доц. \\ С.М. Лукаш, к.е.н., доц. \\ Сумський наџіональний аграрний університет
}

\section{Мінімізація ризиків інноваційного розвитку бізнесу (на прикладі закладів охорони здоров'я)}

\begin{abstract}
Специфічний характер медичної сфери вимагає особливого підходу до надання медичної допомоги з огляду на характер продукту - медичної послуги. Соиіальне значення медичної практики диктує використання спеціальних методів управління. Щороку комериійний сектор охорони здоров'я краӥни постійно зростає, а населення все більше пристосовується до платних медичних послуг. Однак ментальність значної частини населення все ще не дозволяє фактично приймати платну медицину як належн. Варто розуміти, щзо інноваційна діяльність у галузі охорони здоров'я призводить до розвитку медичних технологій, досліджень та найкращчих практик, спрямованих на отримання якісно нової ідеї щодо оздоровлення, лікування, управління процесами в медицині, закупівлі нових медичних виробів, технологій або послуг з конкурентними перевагами.

Стаття присвячена дослідженню теоретико-методичних $i$ прикладних засад мінімізачї ризиків на шляху створення і управління інноваціями у закладах охорони здоров'я.

Сформульовано низку «сил управління на ринку» медичних послуг. До них належать: учасники ринку в цій галузі; фінансування; громадський порядок; технології; клієнти; інвестори (спонсори). Усі вони можуть або сприяти, або перешкоджати впровадженню інновачій. Для того щцоб захистити життя та здоров'я людей, законодавча база в сфері охорони здоров'я вимагає проходження інновацією великої кількості процедур та акредитацій перед впровадженням у стандарти лікування.

Для вдосконалення національного регулювання інновацій у галузі охорони здоров'я у напрямі створення та впровадження інновацій у изьому секторі необхідно постійно контролювати перешкоди на шляху управління інноваційними проєктами для своєчасного виявлення та ефективного управління ризиками. Серед найважливіших напрямів, пов'язаних із підвищенням ефективності управління в закладах охорони здоров'я, безумовно необхідно враховувати умови та можливості реформування процесів управління охороною здоров'я иляхом запровадження нових структурних підрозділів.
\end{abstract}

Ключові слова: управління; заклад охорони здоров'я; інновачії; інноваційний розвиток; ризики.

Актуальність теми. Розвиток закладів охорони здоров'я як ключова складова соціальної політики держави має вирішальне значення для формування іï конкурентоспроможності. Сектор охорони здоров'я має задовольняти потреби громадян у якісних та доступних медичних послугах, що $є$ надзвичайно важливим завданням для України. Існуюче законодавство, політика центральних та місцевих органів влади щодо підтримки інновацій у закладах охорони здоров'я, використання інструментів інноваційного розвитку цього сектору в Україні стало невід'ємною частиною сучасної економіки, залучивши компанії, установи, органи управління на всіх ієрархічних рівнях, що беруть участь у розробці, розповсюдженні та впровадженні новітніх знань для досягнення головної мети - поліпшення якості та рівня життя населення. Тому визначення перешкод та ризиків на шляху створення і управління інноваціями у закладах охорони здоров’я та способи їх мінімізації є актуальним питанням сьогодення.

Аналіз останніх досліджень і публікацій. Дослідження перспективних напрямів удосконалення управління інноваційним розвитком у закладах охорони здоров'я знаходимо у працях таких авторів, як O.I. Амоша, Г.О. Андрощук, О.В. Бондар-Підгурська, Н.Артамова, Л.В. Журавльова, Н.А. Лопина, Л.І. Лозовська, Г.С. Трофименко, Р.Ю. Погоріляк, Д.В. Карамишев, А.С. Немченко, О.О. Єрмоліна [1-11].

Попри наявність певного масиву досліджень і публікацій, присвячених різним аспектам розвитку вказаного питання, мінімізація ризиків на шляху створення і управління інноваціями у закладах охорони здоров'я вивчена недостатньо.

Метою статті $\epsilon$ наукове обгрунтування теоретико-методичних і прикладних засад мінімізації ризиків на шляху створення й управління інноваціями у закладах охорони здоров’я.

Викладення основного матеріалу. Очевидно, що в ході розвитку інновацій у закладах охорони здоров'я виникають нові ідеї, теорії та концепції. Вийшовши на ринок через довгий шлях, лише невелика частина інновацій продовжує бути успішною Цю ситуацію сформував ряд зовнішніх і внутрішніх ризиківбар'єрів [1, с. 16; 2, с. 56-67].

(C) А.М. Бричко, С.М. Лукаш, 2021 
Зовнішні - об'єктивні - бар'єри, що є перешкодою для виходу на ринок, враховують: фінансування; ринковий попит; неконкурентоздатну пропозицію; відсутність досвіду та підтримки автора ідеї інновації; правові бар'єри; складні процеси для включення до стандартів реєстрації та лікування; консервативність сфери (специфіка медицини).

Виходячи із зазначених вище факторів, ми можемо сформулювати низку «сил управління на ринку». До них належать: учасники ринку в цій галузі; фінансування; громадський порядок; технології; клієнти; інвестори (спонсори). Усі вони можуть або сприяти, або перешкоджати впровадженню інновацій в розвиток будь-якого бізнесу.

1. Фінансування. Інновації в закладах охорони здоров’я породжують два типи фінансових проблем: питання фінансування розвитку інновацій та питання про те, хто платить за пропонований товар чи послугу. Однією з проблем є тривалий термін окупності цих інвестицій. У цій галузі нові методи або ліки мають отримувати ліцензії та сертифікати відповідності міжнародним стандартам якості. Ці процедури можуть зайняти роки. Хоча інвестиції у розвиток інформаційних технологій можуть відновитися через два-три роки.

Інша проблема полягає в тому, що багато традиційних джерел фінансування дуже рідко пов'язані 3 охороною здоров'я, і інвестори не мають необхідного досвіду в цьому сегменті. Тому досить складно знайти інвесторів, залучити інвестиційні фонди, які готові інвестувати в інноваційні розробки, більшість 3 яких закінчується невдачею, у сферу, в якій надто мало орієнтуються. Ще складніше знайти інвесторів, які б могли грамотно керувати інноваційним бізнесом у закладі охорони здоров'я. Часто джерелом сумнівів інвесторів є складна модель фінансування та відшкодування витрат на охорону здоров'я, яка, як правило, надходить не від кінцевого споживача, а від третьої сторони, уряду чи приватної страхової компанії [3, с. $32-38 ; 4$, с. $56-62]$.

2. Інвестори. Інвесторам належить ключова роль у впровадженні інноваційного продукту. Через останні події в країні кількість інвестиційних потоків значно зменшилась. Вкладаючи кошти, інвестори вимагають чіткої відповідальності від інноваторів охорони здоров'я. Вони хочуть, щоб технологія продемонструвала економічну ефективність та довгостроковий попит, а також принесла короткостроковий прибуток, швидку прибутковість та відповідну безпеку, яку вимагають регулятори. Інвестиції в охорону здоров’я непопулярні для інвесторів через складні та тривалі клінічні випробування й стандарти лікування. Відновлення таких проєктів може зайняти п'ять, а іноді і всі 15 років. Такі цифри непривабливі для іноземних та вітчизняних інвесторів. Тому більший акцент у цій галузі буде зроблено на пошуку шляхів фінансування громадських, прикладних досліджень та впровадженні нових медичних продуктів, технологій та інновацій.

3. Технологія. Сучасний розвиток медицини та створення нових медичних технологій спричинили ряд проблем, зокрема інновації, розроблені вітчизняними виробниками та їх впровадження, експорт на міжнародні ринки, розробка тактики вибору та впровадження найефективніших медичних технологій, якість та безпека використання тощо. Впроваджуючи новітні методи лікування, профілактики та діагностики в закладах охорони здоров’я, важливо звертати увагу на процес вибору медичної технології. Економічна доцільність використання інноваційних медичних технологій визначатиметься шляхом отримання результатів аналізу економічної ефективності та витрат. Критеріями вибору інноваційних медичних технологій та їх впровадження для надання вузькоспеціалізованої медичної допомоги у закладах охорони здоров’я мають бути: унікальність медичної послуги або технології; безпека; економічна та клінічна ефективність; виявлення соціально значущої або рідкісної хвороби.

Крім того, впровадження інновацій у закладах охорони здоров'я та нових медичних технологій вимагає розуміння того, коли організаціям, що впроваджують інновації, потрібно виходити на ринок разом 3 ними. Якщо ви вийдете на ринок занадто рано, інфраструктура, необхідна для підтримки інновацій, може бути не готова; відкладаючи інновації на довгий час, ви можете втратити свою конкурентну перевагу. Ми повинні мати на увазі, що конкуренція застосовується не тільки в межах одного регіону, але і між різними регіонами, орієнтованими на певні категорії захворювань [5, с. 134-146; 4, с. 56-62].

4. Клієнти (попит). Іншим важливим моментом у створенні інновацій у закладах охорони здоров'я $\epsilon$ правильне визначення цільової групи та цільової групи медичних виробів, технологій, методів тощо та потенційного споживача. Слід розуміти, що кінцевий споживач часто не є цільовою групою. Цільовими споживачами лікарського засобу є родичі пацієнта, відповідні методи лікування та лікарі, що виписують лікарські засоби, та страхові компанії, які можуть частково компенсувати кошти та часто не підтримують нові медичні винаходи. Дуже часто споживачі ігнорують медичні поради, використовуючи інформацію 3 Інтернету. Тому компанії, які знають та використовують Інтернет як джерело інформації про свій інноваційний продукт, можуть значно підвищити сприйняття ринком інновацій. Сучасні інновації в закладах охорони здоров'я вимагають значних інвестицій, а отже, мають високі кінцеві витрати для споживача. Це ще один фактор обмеженого попиту на дорогі, інноваційні продукти, ліки чи технології, що в свою чергу призводить до недоступності цих послуг для пересічного українського споживача, який не має достатніх фінансових ресурсів для задоволення своїх потреб. 
5. Гравці на ринку. В управлінні закладах охорони здоров'я є багато зацікавлених сторін, усі зі своїми прихованими планами та мотивами. Часто ці суб'єкти мають ресурси та здатність впливати на державну політику, передбачаючи або підтримуючи новаторів [6, с. 13; 7, с. 23-27]. Інновації в галузі охорони здоров'я, інноваційні медичні технології дають можливість закладам охорони здоров'я підвищити ефективність лікування та ведення пацієнтів, скоротити час діагностики тощо. Поява нововведень у медицині призводить до необхідності перегляду та зміни концептуальних положень патогенезу різних захворювань, зміни психіки та вдосконалення знань і навичок лікарів, впровадження абсолютно нових підходів до повсякденної діяльності. Здебільшого лікарні та лікарі виступають проти сучасних технологій через високі витрати на лікування. Крім того, прихованою причиною для деяких лікарів може бути небажання освоювати нові сучасні технології. Проблемою України, як і раніше, залишається підготовка медичних фахівців, інноваційні технології, відтік кваліфікованих фахівців за межі нашої країни [8-10]. Незважаючи на досить потужну мережу медичних коледжів, Україна ще не досягла рівня клінічної та фундаментальної підготовки лікарів, який повністю відповідає сучасним міжнародним стандартам.

6. Брак досвіду. Ще однією перешкодою для реалізації інноваційних проєктів $є$ відсутність практичного досвіду та налагоджених механізмів реалізації ідеї. На жаль, у світі науки та застосування існує великий розрив, відсутність практичних навичок застосовувати ідею до реального продукту.

Дуже слабо розвинута співпраця між науковими інститутами та приватним бізнесом чи державними установами, в яких є не тільки фінансові можливості, але й практичний досвід 3 виводу нових продуктів на ринок. Тому більшість інноваційних ідей зупиняється на першому етапі їх практичної реалізації, оскільки перших кроків у їх реалізації немає через відсутність відповідного досвіду ініціатора. Найважливішими показниками практичної діяльності в галузі охорони здоров'я $\epsilon$ ефективність впровадження нових медичних технологій, інновацій, що застосовуються в клінічній практиці, частка тих, хто впроваджує різні інновації (розробка та впровадження нових або вдосконалених продуктів, робіт) у галузі охорони здоров’я, заклади, служби, технології, процеси тощо.

7. Політика. Національні норми охорони здоров’я іноді можуть допомогти запровадженню інновацій, а іноді перешкоджають їм. Тому компаніям, які займаються розробкою інновацій у цій галузі, необхідно ретельно вивчити законодавство, щоб чітко зрозуміти, які закони можуть допомогти реалізувати їхні ідеї, а які можуть завдати їм шкоди.

Україна ще не має державного стимулювання для компаній, що розробляють інноваційні продукти, $\mathrm{i}$ в той же час не створює сприятливого податкового та інвестиційного середовища, яке б дозволило компаніям розробляти стратегії інноваційного розвитку й інновацій у галузі охорони здоров'я. Для того щоб захистити життя та здоров'я людей, законодавча база в сфері охорони здоров'я вимагає проходження інновацією великої кількості процедур та акредитацій перед впровадженням у стандарти лікування. Правова та організаційна основа передачі деяких медичних послуг приватним особам триває. Крім того, держава не стимулює передачу медичних послуг приватному сектору [11, с. 143; 10, с. 23-26]

Щоб полегшити подолання всіх видів ризиків, фактори, що обмежують сприйнятливість до інновацій, мають бути детально вивчені. Тому оцінка ризику проєкту є важливим кроком перед його початком. Інновації в галузі охорони здоров'я залежать від управління ризиками. Під час здійснення інноваційного проєкту важливо враховувати всі ризики, а також заходи, спрямовані на попередження, зменшення ризику. 3 іншого боку, ризики можуть бути позитивними. У разі настання позитивного ризику потрібно мати альтернативний варіант дій. Ризик інноваційного проєкту у галузі охорони здоров'я є показником невизначеності, який необхідний для досягнення очікуваного рівня рентабельності в реальних умовах бізнесу при реалізації інноваційного проєкту, тому необхідно розробити методи запобігання, зменшення або компенсації можливих негативних наслідків [11].

Рекомендується оцінити ризикованість інноваційного проєкту та ймовірні витрати у разі ризикованої події. Чим пізніше ідентифікується ризик, тим більша ймовірність та значущість завданої шкоди, що ускладнює досягнення цілей. Основними кроками в оцінці ризику інноваційних проєктів у закладах охорони здоров'я є:

1) виявлення індивідуальних ризиків реалізації інноваційного проєкту в закладі охорони здоров'я. Водночас необхідно виявити ризики, які можуть виникнути в будь-який момент інноваційного проєкту, та провести детальний аналіз ризиків, систематизацію ризиків з урахуванням типології, очікуваних перешкод $[11$, c. 143$]$;

2) збір інформації для визначення рівня ризику окремих проєктів;

3) вибір та використання відповідних методів для оцінки ймовірності ризиків окремого проєкту $[9$, c. $57-60]$;

4) визначення суми можливих фінансових наслідків для настання ризикованих подій у зв'язку із впровадженням інновації та реалізацією інноваційного проєкту у галузі охорони здоров’я [6, с. 37];

5) загальна оцінка ризику проєкту закладу охорони здоров'я;

6) порівняння рівня ризику проєкту з фінансовою спроможністю суб'єкта господарювання у галузі охорони здоров'я; 
7) порівняння рівня ризику проєкту сектору охорони здоров'я з рівнем прибутковості інноваційного проєкту. Фінансово-господарська діяльність суб'єкта господарювання базується на максимізації прибутку, тому сума витрат має відповідати величині прибутку, отриманого в результаті реалізації інноваційного проєкту.

Висновки та перспективи подальших досліджень. Для вдосконалення національного регулювання інновацій у галузі охорони здоров'я у напрямі створення та впровадження інновацій у цьому секторі необхідно постійно контролювати перешкоди на шляху впровадження та управління інноваційними проєктами для своєчасного виявлення та ефективного управління ризиками й дотримуватися таких заходів: реформувати нормативно-правову базу в галузі охорони здоров'я; модернізувати інформаційну складову системи охорони здоров'я на основі передових IT-інновацій; забезпечити активне спілкування та ефективну співпрацю між різними структурними підрозділами системи охорони здоров'я. Це дасть можливість створити регіональні бізнес-асоціації, які сприяють ефективному розподілу влади, вдосконалити систему моніторингу, запровадити громадський контроль за діяльністю української системи охорони здоров'я.

\section{Список використаної літератури:}

1. Амоша O.I. Інноваційний шлях розвитку України: проблеми та рішення / O.I. Амома // Економіст. - 2005. № 6. - C. 16-31.

2. Андрощук Г.О. Національні інноваційні системи: еволюція, детермінанти результативності : монографія / Г.О. Андрошук ; ред. С.А. Давимук, Л.І. Федулов. - Київ : Парламентське видавництво, 2015. - 510 с.

3. Бондар-Підгурська О.В. Науково-методологічні засади сталого інноваційного соціально орієнтованого розвитку економіки : монографія / О.В. Бондар-Підгурська. - Полтава : ПУЕТ, 2016. - 531 с.

4. Артамова $H$. Інформаційний моніторинг наукової та інноваційної діяльності медичної галузі України / Н.Артамова // Бібліотечний Вісник Інституту медичної радіології ім. С.П. Григорьєва АМН України. 2007. - № 2. - С. 10-13.

5. Божко В.П. Влияние инноваций на уровень международной экономической интеграции / В.П. Божко. Харьков : Национальный аэрокосмический университет им. Н.Е. Жуковского «Харьковский авиационный институт», 2015. - $115 \mathrm{c}$.

6. Журавлева Л.В. Информационно-образовательное пространство в работе клинической кафедры в контексте реализации непрерывного медицинского образования : метод. реком. / Л.В. Журавлева, Н.А. Лопина. Харьков : ХНМУ, 2015. - 36 с.

7. Лозовська Л.І. Моделювання систем управління в галузі охорони здоров'я : монографія / Л.І. Лозовська, Г.С. Трофименко. - Дніпропетровськ : Герда, 2015. - 197 с.

8. Погоріляк Р.Ю. Характеристика якості та доступності надання вторинної та третинної медичної допомоги населенню на регіональному рівні / Р.Ю. Погоріляк // Науковий вісник Ужгородського університету. Сер. : Медицина. - 2015. - Вип. 1 (51). - С. 299-301.

9. Охорона здоров'я України: стан, проблеми, перспективи / В.В. Лазоришинець та ін. ; за ред. В.В. Лазоришиния. - Київ, 2014. - 607 с.

10. Карамишев Д.В. Реалізація та оцінка ефективності інноваційних проектів у системі охорони здоров'я / Д.В. Карамишев, А.С. Немченко // Економіка та держава. - 2006. - № 2. - С. 86-88.

11. Бричко А.М. Впровадження та розвиток інновацій у сфері охорони здоров'я / А.М. Бричко, О.О. Срмоліна // Інтеграція освіти, науки та бізнесу в сучасному середовищі: літні диспути : матеріали II міжнар. наук.-практ. інтернет-конф., 17-18 серпня. - Дніпро, 2020. - С. 189-191.

\section{References:}

1. Amosha, O.I. (2005), «Innovacijnyj shljah rozvytku Ukrai'ny: problemy ta rishennja», Ekonomist, No. 6, pp. 16-31.

2. Androshhuk, G.O. (2015), Nacional'ni innovacijni systemy: evoljucija, determinanty rezul'tatyvnosti, monografija, in Davymuk, S.A. and Fedulov, L.I. (ed.), Parlaments'ke vydavnyctvo, Kyi'v, 510 p.

3. Bondar-Pidgurs'ka, O.V. (2016), Naukovo-metodologichni zasady stalogo innovacijnogo social'no orijentovanogo rozvytku ekonomiky, monografija, PUET, Poltava, $531 \mathrm{p}$.

4. Artamova, N. (2007), «Informacijnyj monitoryng naukovoi' ta innovacijnoi' dijal'nosti medychnoi' galuzi Ukrai'ny», Bibliotechnyj Visnyk Instytutu medychnoi' radiologii' im. S.P. Grygor'jeva AMN Ukrai'ny, No. 2, pp. 10-13.

5. Bozhko, V.P. (2015), Vliyanie innovatsii na uroven' mezhdunarodnoi ekonomicheskoi integratsii, Natsional'nyi aerokosmicheskii universitet im. N.E. Zhukovskogo «Khar'kovskii aviatsionnyi institut», Khar'kov, 115 p.

6. Zhuravleva, L.V. and Lopina, N.A. (2015), Informatsionno-obrazovatel'noe prostranstvo $v$ rabote klinicheskoi kafedry v kontekste realizatsii nepreryvnogo meditsinskogo obrazovaniya, metod. rekom., KhNMU, Khar'kov, 36 p.

7. Lozovs'ka, L.I. and Trofymenko, G.S. (2015), Modeljuvannja system upravlinnja v galuzi ohorony zdorov'ja, monografija, Gerda, Dnipropetrovs'k, 197 p.

8. Pogoriljak, R.Ju. (2015), «Harakterystyka jakosti ta dostupnosti nadannja vtorynnoi' ta tretynnoi' medychnoi' dopomogy naselennju na regional'nomu rivni», Naukovyj visnyk Uzhgorods'kogo universytetu, Ser. Medycyna, Issue 1 (51), pp. 299-301.

9. Lazoryshynec', V.V. et al. (2014), Ohorona zdorov'ja Ukrai'ny: stan, problemy, perspektyvy, in Lazoryshyncja, V.V. (ed.), Kyi'v, 607 p. 
10. Karamyshev, D.V. and Nemchenko, A.S. (2006), «Realizacija ta ocinka efektyvnosti innovacijnyh proektiv u systemi ohorony zdorov'ja», Ekonomika ta derzhava, No. 2, pp. 86-88.

11. Brychko, A.M. and Jermolina, O.O. (2020), «Vprovadzhennja ta rozvytok innovacij u sferi ohorony zdorov'ja», Integracija osvity, nauky ta biznesu v suchasnomu seredovyshhi: litni dysputy, materialy II mizhnar. nauk.-prakt. internet konf., 17-18 serpnja, Dnipro, pp. 189-191.

Бричко Аліна Михайлівна - кандидат економічних наук, доцент кафедри публічного управління та адміністрування Сумського національного аграрного університету.

https://orcid.org/0000-0003-4902-1403.

Наукові інтереси:

- сталий розвиток;

- державна підтримка та регулювання;

- управління інноваційним розвитком;

- започаткування власної справи.

E-mail: researcheimsnau@gmail.com.

Лукаш Світлана Миколаївна - кандидат економічних наук, доцент кафедри публічного управління та адміністрування Сумського національного аграрного університету.

https://orcid.org/0000-0003-1948-7683.

Наукові інтереси:

- інвестиції в сільське господарство;

- бізнес-менеджмент;

- сталий розвиток сільського господарства.

E-mail: svitlana.lukash@gmail.com. 